\title{
NATIVE AMERICAN ECONOMIC DEVELOPMENT: A MODERN APPROACH
}

\author{
Dean Howard Smith*
}

\begin{abstract}
Recent approaches to problems facing Native American reservation economies address practical solutions to the severe poverty and associated socioeconomic ills while recognizing cultural and sovereignty issues as opposed to simply listing the historical causes of these issues. This paper integrates some of the work completed in the last decade in order to understand the feasibility and processes of sustained cconomic development on Native Americen reservations. Undarstending development as a process, rather than a black or white phenomenon, leaves the planner with an optimietic vantage point on the possibilities of success. It is this process orientation that holds the focal point of this paper. Using the Rosebud Sioux Reservation as an exemplar, Jacobs's (1984) model provides a paradigm for the development process. Understanding the model puts us in a position to fully understand the development possibilities in Indian country as well as the problematic aspects.
\end{abstract}

\section{INTRODUCTION}

Recent approaches to problems facing Native American reservation economies address practical solutions to the severe poverty and associated socioeconomic ills while recognizing cultural and sovereignty issues as opposed to simply listing the historical causes of these issues. Undertakings such as the Harvard Project on American Indian Economic Development and Northem Arizona University's Center for American Indian Economic Development have focused attention on pragmatic solutions to specific development issues. A joint project of Northem Arizona and Harvard Universities, the National Executive Education Program for Native American Leadership (NEEPNAL), works directly with tribal govemments and enterprises in educating leadership and designing task-specific solutions. This paper integrates some of the work completed in the last decade with interviews with various tribal leaders in order to understand the feasibility and processes of sustained economic development on Native American reservations.

\footnotetext{
*The author, a Mohawk, is Assistant Professor of Economics at Northern Arizona University. The author wishes to thank Hamp Merrill for his help in this and other projects concerning Indian country. The author also wishes to thank his undergradunte and graduate students for their insights and willingness to learn new and diverse ideas concerning the economic development of the reservations. Additionally, thanks are due Steve Comell and Henry Herzog for their helpful suggestions. Finally, anonymous referees provided detailed comments and suggestions on earlier drafts of this paper. The usual caveat maintains. Partial support for this project was provided by the Center for American Indian Economic Development at Northem Arizona University and the National Executive Education Program for Native American Leadership.
} 
To accomplish this aim, the paper begins with a discussion of the Rosebud Sioux Reservation and an outline of a proposed set of development projects as discussed in Diamant (1988). Throughout this paper, Rosebud will act as a tangible exemplar for the general ideas presented. Then a working definition of sustained economic growth from Jacobs (1984) is detailed. The development framework is then used to systematically address a development scheme for the Rosebud Sioux Reservation using various examples from other reservations. Following discussion of an integrated plan, a very brief discussion of some of the obstacles to development is presented. The paper concludes with a look forward.

While the intent of this paper does not include making light of the issues facing the Native American tribes, it does aim to show that development can occur in a modem economic framework within the constraints of maintaining cultural and sovereign integrity. Ideas and concepts, such as the Grand Canyon Trust's community initiatives project and the First Nations Financial Project, can be realized and put into action. ${ }^{1}$ Such action can and will facilitate development of the subject economies. Another use of this paper is an application to other lesser developed economies, keeping in mind the sovereignty and legal issues specific to the First Nations.

\section{ROSEBUD SIOUX}

The difficulties facing the reservations' economies may reach a pinnacle on the Rosebud Sioux Reservation in South Dakota. ${ }^{2}$ Diamant (1988) conducted a detailed study focusing on possible enterprises for the tribe or tribal members to undertake in promoting economic development. However, his study was not particularly optimistic about the potential success of development. This section first provides a descriptive overview of demographic data of the reservation and then presents an overview of Diamant's suggested activities. Following presentation of the Jacobs model, this list of possible outlets for prosperity provides an argument that a consolidated development plan could lead to the envisioned economic development within the confines of cultural and sovereign integrity.

Preliminary data from the 1990 Census on Housing and Population show some important distinctions between the Rosebud Sioux Reservation and both South Dakota and the United States as a whole. ${ }^{3}$ Rosebud has a population of 8,352 , which is almost exactly 50 percent male and 50 percent female $(4,132$ male vs. 4,220 female), ${ }^{4}$ which compares to 51.2 percent female for the United States as a whole and 50.8 percent for South Dakota. The most glaring result of this comparison is the large percentage of the reservation population under the age of 18. People under the age of 18 account for 45.1 percent of the population. In com- 
parison, 28.5 percent of South Dakota's population is under 18, and the U.S. figure is $\mathbf{2 5 . 5}$ percent. Similarly, Rosebud has only 8.5 percent of the population older than 60: South Dakota and the United States are 19.1 percent and 16.9 percent, respectively. Experience in Indian country leaves the author with the following understanding for this result. First, due to poor nutrition, social problems, and health care in past years, the life expectancy of Native Americans has been lower than the population as a whole; therefore, there are fewer elders on the reservation. Compounding this, and more important in terms of economic development plans, is the fact that improved health care and altering social problems have resulted in a significant increase in the number of successful pregnancies and the number of teenage pregnancies, which has increased the number of childnen as well as the percentage of children. Regardless of the causes for this shift in the age distribution, the fact remains that the reservation population has in excess of 45 percent of its population in the school-age years. The socioeconomic problems present on the reservation will become more problematic as this cohort enters their working years unless economic development occurs. ${ }^{5}$ These data accentuate the need for improved education programs and point to a major change in the demographics of Indian country.

The data also show a significant difference in the makeup of families. The percentage of single parent families, both male- and female-headed, is higher than South Dakota and the United States as a whole. The figures for Rosebud are 9.3 percent and 28.7 percent, respectively. South Dakota has 2.7 percent of all households as male-headed and 8.0 percent as female-headed. The numbers for the United States are 3.4 percent and 11.6 percent respectively.

Proxy data with regards to standards of living show significant differences in home values and average monthly rents between the reservation and off-reservation sites. Furthermore, the differences are more pronounced when isolating those homes owned or rented by Native Americans. For example, the average owneroccupied home deeded to a Native American has a value of $\$ 23,700$; whereas the average white-owned home in the United States has a value of $\$ 113,700$, which is nearly five times the value of homes on Rosebud. Similarly, the average rent paid by Native Americans on the reservation is $\$ 124$. The white comparisons are $\$ 160$ for on-reservation sites and \$429 for the United States as a whole. These differences can be used to infer differences in living standards.

These preliminary data all tend to point toward significant socioeconomic problems on the Rosebud Sioux Reservation. Although Rosebud may be considered one of the poorest reservations, these data are representative of many reservations when compared to non-reservation locations.

The data show a significant need for economic development among the Rosebud Sioux. As the young population ages and becomes of working age, un- 
employment and concomitant social problems will only become more problematic. A more complete data analysis, beyond our current scope, would only support this conclusion. Further, a cross-sectional study of different reservations would show these problems to be pandemic on most reservations. The work completed by the Harvard Project on American Indian Economic Development and by the National Executive Education Program for Native American Leadership, in part, attempts to decompose the reasons why some reservations are relatively successful. For an introduction to this work, see the work edited by Comell and Kalt (1992b). Whether the focus is on Rosebud or a generalized theory of reservation development, current living standards on reservations are well below the mainstream economy.

Diamant (1988) studied the Rosebud Sioux Tribe and describes a variety of development ideas. The potential enterprises include the following. The Forest Products Enterprise could be expanded by increasing the harvest of trees and the scope of operations to include lumber processing for construction and picnic tables. A commercial fish hatchery could replace currently imported hatchlings as well as develop a new export product. The import-replacing aspects can be viewed as an intermediate product, improving tourism gleaned from tourismbased fishing permits. Additionally, Diamant suggests the tribe expand and develop its hunting permit sales through herd and range management. The game available includes elk, buffalo, and antelope herds as well as deer and small game. This is seen as export expansion. Due to high levels of geothermal power, the tribe could develop aquaculture and silvaculture enterprises to grow food products and saplings for both import-replacing and export purposes. In addition to harvesting and utilizing the natural resources, Diamant discusses the development of a microelectronics plant and a garment manufacturing enterprise. Both of these enterprises could gain a comparative advantage due to Section 8(A) certification. ${ }^{6}$ He also emphasizes expanding the local arts and crafts industry in terms of both quality and quantity.

Diamant suggests a long-term goal of developing the tourism industry once the amenities and social conditions of the reservation have been improved. He also suggests, most importantly for our purposes, providing incentives for locally selling goods and services: namely, developing retail services available on the reservation.

The question arises conceming how to take these development plans and make them, or others, successful given the current economic status of the reservation. The following model provides a methodology for analyzing the development process. 


\section{THE JACOBS MODEL}

Jacobs (1984, specifically, see p. 173) provides a conceptual framework for understanding regional development. This is termed the "Cycle for Vigorous City Growth." A four-stage cycle is suggested for sustained economic growth. This section briefly discusses the background ideas of Jacobs's cycle in the context of reservation economies. ${ }^{7}$ Various success stories and comments from Indian country are used as examples of the process.

The first stage of the cycle of growth involves an initial export industry eaming imports. At first glance, it might be said that an economy facing an excess of 50 percent unemployment and concomitant dire poverty does not have many such export industries; however, reservation economies clearly have the ability to import products. Tribes do earn revenues from extractive enterprises such as mines, forestry projects, and water sales. Other tribal and private enterprises provide some degree of earnings. A variety of federal, state, and tribal government activities provide additional employment. Besides these salaries, royalties, and profits eamed from tribal activities, other major sources of funds are transfer payments and trust account earnings. Therefore, most tribes do satisfy the requirement of eaming imports. Moreover, private imports are typically purchased from the border towns on day trips by residents spending transfer and other income. ${ }^{8}$ Thus, the first stage of the cycle is satisfied.

The second stage, and one of primary importance in the current context, is the development of import-replacing industries within the local economy. In this stage, the reservation economy begins to produce locally hitherto imported products. In terms of reservation economies, this initially means an increase in retail and service activity. An extension of this idea is the advent of actually producing some of the products previously imported.

The import replacement phase does not reject the tenet of comparative advantage; rather, it expands upon the understanding that trade pattems should follow well-known economic fundamentals. The forcefulness of the importreplacing idea rests on the understanding that comparative advantages are not static in nature. ${ }^{9}$ By reducing transport distances and developing new and improved technology-not to mention lowered wage rates on the reservation, a tribe may well be able to replace some previously imported products at a cost savings. For example, relatively low wage rates on the reservations make the location of business activity more profitable. Since wages rates average $\$ 4.10$ per hour in Hong Kong, Korea, Singapore, and Taiwan (Pomice and Hawkins 1992), there is a competitive advantage for reservations when transportation costs are factored in. Thus, potential development of manufacturing and assembly type work is significant. ${ }^{10}$ Additionally, several federal programs aimed at advancing minority- 
owned businesses, such as $\mathbf{8}(\mathrm{A})$, present opportunities for tribally owned and privately owned businesses. The problem is to properly identify those products that can be successfully produced by the tribe, which of course is the question any development plan must answer. Regional science has produced various techniques to help determine the sectors and industries potentially ripe for expansion, but these problems are beyond the scope of the current discussion. Clearly, the import activities to be replaced are reservation specific, but once the products and services are identified and the tribe begins to domestically produce the product, it is then possible that the direction of the comparative advantage actually reverses through the process, which is the next stage in the cycle.

The third stage involves developing new and innovative products and production techniques during the import-replacing phase. For example, modem Navajo arts and crafts industries include world-renown techniques for weaving and silversmithing. Techniques for dying and spinning wool have progressed from rudimentary ones to advanced techniques allowing for intricate designs and pattems. Originally, these industries were developed by Navajos for domestic consumption of jewelry and blankets; however, these industries are now significant sources of income for individual artisans and the tribally managed Navajo Arts and Crafts Enterprise.

The fourth stage encompasses developing these new techniques and products into new export industries, which provide increased or substitute import-earning income. At this stage, the process cycles: new import replacing takes place, new products are developed, and, in tum, a new phase of exports are cultivated. Thus, a cycle of vigorous growth obtains.

For example, consider the following. The White Mountain Apache Tribe in Arizona has a small manufacturing facility producing parts for the Apache helicopter manufactured by McDonnell-Douglas. After five years of operation, the tribe is expanding from simple "cut and sew" operations to more advanced production. The planned expansion of Apache Aerospace involves diversified products and an increased marketability to aerospace companies other than McDonnell-Douglas. The new "technology" utilized includes that provided under Mentor-Protege legislation. ${ }^{11}$ Marilyn Endfield vigorously lobbied for the passage of this legislation (Endfield 1992, see below). ${ }^{12}$

The process of sustained development is best described by Jacobs herself: Any settlement that becomes good at import replacing becomes a city. And any city that repeatedly experiences, from time to time, explosive episodes of import replacing keeps its economy up-to-date and helps keep itself capable of casting forth streams of innovative work. Why "explosive" and why "episodes"? In real life, whenever import replacing occurs significantly at all, it occurs in explosive 
episodes because it works as a chain reaction. The process feeds itself, and once well under way, does not die down in a given city until all imports that are economically feasible to replace at that time and in that place have been replaced (1984, 41; emphasis in original).

Jacobs states that any "settlement" can become involved with the development process. This author vigorously believes this process can be applicable to reservation economies. Jacobs argues that what makes a "city region" a cohesive entity is a central identity. Nowhere is this identity more pronounced than on and near reservations. Jacobs also argues-as do other regional analysts-that political borders are unimportant in the development process, except for defining legal systems and their impacts. Keeping with that thought, what makes a reservation and the border towns a cohesive whole is the cultural and economic linkages existing within a definable region with a definable population. Jacobs's model begins with no other precondition other than an initial earnings of imports, which currently occurs within reservation economies. She also explains growth and development as a process and not a static burst of energy. Thus, the "explosive episodes" in Indian country will start small and grow over time. The initial episode will likely evolve over the next 15-20 years. This follows $100-500$ years of stagnation and deterioration.

Growth occurs from the import-replacing and export-development process due to five interwoven factors. First, as import replacing occurs, an increased number and diversity of employment opportunities develop. Second, as employment eamings increase, and the multiplier effect obtains, the region has enlarged import markets providing new and different products. Third, as activity and employment increase, jobs and activity spread outward from the city hub to the hinterland, thereby increasing economic activity in the surrounding areas. Fourth, as the process continues, there will be new uses for existing technology and new technological developments as entrepreneurial activity occurs. And last, as the process proceeds and new businesses are opened, there will be an increase in the capital stock of the city region. These five forces lead to increased economic activity and employment, and in tum foster the development of the cycling of growth: new exports earning increased and new imports.

Tribal concerns for creating master plans for development envelope their understanding of progress as required to take them from their current situations to a position of self-determination and self-sufficiency. Barbara Ward describes the need for an overall plan of action as follows:

All parts of the economy have to be affected if the economic pattem as a whole is to change. A little modification here, a little development there, may transform parts of the economy, but it is only when 
the flood of change begins to run right through society that you get that actual "breakthrough" to a new type of productive economy ... (Ward 1962, 34).

Thus, Jacobs understands development as a process governing the entire economy and that the entire economy must take part in the progress. Furthermore, Jacobs's model does not simply apply to existing city centers; rather, it applies to any cohesive society striving for development: i.e., it is a relevant model for reservation strategies.

While the Jacobs model is segmented into individual phases, it does so because of the necessity for narrative simplicity. In a practical sense, the cycle is an ever-changing motif of phases for different industries and sectors. As such, the individual parts of the whole need not be mutually exclusive. Import replacing of one product can occur side by side with export development of another service. Also, export development need not be a direct result of import replacement; rather, some exports may result as a sole effort to increase import-earning potential without any intention of local consumption. For example, consider White Mountain Apache's success in producing component parts for the Apache helicopter: other than for demonstration purposes, none of the final product is of any use to this tribe.

Jacobs's use of the term "city" is initially used to identify an economic aggregation of activity where the bulk of economic activity is based on interactions within that region. In many cases, this centering node for this activity is an identifiable city. However, she uses examples focusing on national regions and small town regions. She further considers supply regions and transplant regions. Therefore, her model of a "vigorous city" is in no way confined to large city centers but instead extends to any cohesive region. Reservation economies, particularly geographically isolated ones, have all the characteristics of a connected region as mentioned above. Furthermore, many off-reservation border towns are part of the reservation economy, not the other way around. One of the goals of import replacing retail and service industries onto the reservation is to tighten the economic ties within the reservation and to limit those with off-reservation businesses. Recalling the above quote, Jacobs describes the process of development as defining a vigorous city, which does not require the existence of a certain population size or density.

Considering Jacobs's model, two important aspects are required for local reservation development. First, import replacement takes advantage of the multiplier effect. According to one study, 87 percent of the Navajo Nation's disposable income is spent off the reservation (Yazzie 1989). If reservations are to develop, leakages to border towns must be diminished. President Steele, of the Oglala Sioux Tribe, states: "Spending that dollar in our jurisdiction-at least once if not 
more than once" is an important goal (Steele 1992). This is a fundamental and familiar conclusion. As mentioned previously, import-replacing retail and service industries onto the reservation will stimulate economic activity. In a very real sense, trade deficits between the reservation and the mainstream economy limit the effects of the multiplier effect. (Counterbalancing the importance of domestic production are the benefits of trade due to comparative advantage. See Endnote 10.) Keeping eamed surpluses revolving within the local economy enhances employment and incomes within that economy. Either an economy must increase its domestic trade through the multiplier effects, or it must increase its exports to eam increased imports. Import replacing and increased domestic production do not work against export development; rather, the sectors work in conjunction and enhance each other.

Second, increasing economic viability of these economies requires developing export enterprises: without interaction with the global economy, reservations are facing isolation, which leads to continued subservience. Exports earn income for the domestic economy. These increased eamings can either be used to purchase increased imports, or they can be filtered through the domestic economy and expended due to the multiplier effect. The benefits of trade due to comparative advantages need to be balanced with the secondary and tertiary effects of domestic economic activity. The success of the Japanese economy is proof of this idea.

Therefore, most tribes need to form a two-pronged attack in their economic development plans. A mixture of import replacing and increased export development accelerates the multiplier mechanism. Combining this with a meaningful and purposeful increase in imports will allow the reservation economies to improve their self-sufficiency and economic freedom. Besides the multiplier effects and the increased employment opportunities that lead to higher standards of living, there will also be a reduced reliance on government employment. President Steele mentions the problems of relying on government employment due to the scarcity of other opportunities: "People are interested in federal service jobs and not the goals, services and roles of those jobs" (Steele 1992).

At this point, a clarification is necessary. The Jacobs model denotes the importance of import replacing; however, the aim of economic development is to develop new or at least increased exports, thereby increasing incomes and earning increased imports. In general, the end implies the middle, but this need not be the case. ${ }^{13}$ Take for instance the Yavapai-Prescott reservation. This small reservation currently runs a successful gaming operation and leases land to ITT for a Sheraton conference center. Neither of these two enterprises is aimed at import replacement; rather, this tribe jumped straight to the export development phase. ${ }^{14}$ Thus, the tribe is able to earn increased imports, i.e., has increased income without 
benefits of the multiplier effect or import replacing. This example does not diminish, however, the general importance of the import replacement phase as an important step in the development process. Very small tribes or bands located near a city may be able to develop by attracting the border town to reservation activities, whereas larger tribes most likely need to develop their own economic infrastructure.

The Jacobs model views development as a process. Many analysts of her work view it as applicable only to existing and large cities; however, it is her thesis that it was this very process that allowed the large cities to develop in the first place. Therefore, the model is applicable to reservation economies. What follows is an exemplar of how this process might help the Rosebud Sioux progress.

\section{AN INTEGRATED PLAN}

Diamant concludes that nearly all of the proposed ventures are likely to be insufficient for the Rosebud Sioux to realize economic self-sufficiency. However, he fails to recognize two possible avenues for success. First, he treated each activity individually with no agglomerating factors existing between activities. Second, excepting tourism, he focuses on a rather short-term or static planning horizon. This section provides a new understanding of the proposed ventures as an integrated development plan.

Several of the opportunities suggested by Diamant can be viewed, in the Jacobs framework, as being purely import replacing. These include retailing and construction. These ventures would accomplish several of the steps necessary to initiate a cycle of vigorous growth.

First, the well-recognized concept of the multiplier bears importance here. For instance, developing retail services available to local residents keeps import eamings on the reservation for at least one more round of local spending. Of course, this leads to additional local employment and income subsequently captured by the local multiplier. In Indian country, the term "Buy Indian" does not apply to the 1910 federal set aside law; rather, it means reservation residents purchasing from local retail shops.

In addition to the income effects, the employment multiplier comes into play. This is further advanced in conjunction with the advent of other proposed enterprises. As those businesses increase local and export industries, local employment increases, which leads to increased local sales, if local retail opportunities have also increased. However, if there is no increase in the retail sector, then the border towns experience the multiplier effect. 
A third influence of increased retail activity on the reservation is more sociological than economic. Increased income and employment have positive influences on both employees' families and the local population as a whole. ${ }^{15}$ Whereas retail employment is generally low-skill, entry-level employment, it provides an introduction to general employment skills, which can be subsequently useful when the employee moves on to more advanced employment. Increased income provides incentives for other family and community members to actively consider searching for employment. However, this only benefits the tribe if other employment is available. Otherwise, the small increase in local employment can actually lead to conflict. Thus, the direct import-replacing activities advance the local economy if it is merged with the development of other activities that include career-ladder opportunities.

Diamant also proposes developing enterprises that may be termed expanded or new export industries. These include arts and crafts, hunting, fishing, microelectronics, and garments. Increasing export activity increases the earnings of imports. For example, increasing the sale of buffalo permits provides income for the tribe through additional license fees or profits as well as increased income for the employees of the expanded enterprise. This new income earns additional purchases of goods and services from the off-reservation economy. However, if a substantial portion of these expanded purchases are made through the above-mentioned (expanded) retail sector, then the multiplier effect once again is activated.

Diamant further suggests mixed purpose activities. If timber is locally processed and both exported and import replaced, then a combination of the above developments is obtained. Local construction of domestic dwellings occurs, which can now be financed through income effects of the local multiplier and increased imports. This new secondary development leads to increased multiplier effects, which in turn begins the second cycle of vigorous growth.

In isolation, Diamant concludes that any one of these activities is likely to fail as a profitable enterprise or to result in sustained development on Rosebud. However, when taken as an integrated plan of action, the various factors work together to support each other as an agglomerating force. Initially, these agglomerating forces may be small or even nonexistent. For this reason, it may require a true entrepreneurial spirit to get the process started. This could be a tribal enterprise such as Apache Aerospace where the agglomerating forces become intertwined with economies of scope, or it may be a tribal member accepting the risk. Once the initial enterprise begins to grow and show promise, the agglomerating forces will grow as the tribe and tribal members begin to see the success. In addition, the likely time frame of each enterprise adds support to the integration idea. 
The easiest enterprise to begin is retail activity; timber activity, on the other hand, is likely to take one to three years to get on line. During this period, expansion in retail services is likely to be exploratory and slow. Then, by the time the expanded timber efforts begin to see signs of fruition, the retail sector should be prepared for expansion. The next phase is increasing the lumber capacity and subsequently the construction capacity. As the local economy expands, the retail sector can be expanded, and the cycle continues.

As the economy of the Rosebud Sioux reservation develops, new ideas and possibilities will develop. In other words, Jacobs's model of vigorous growth continues as new services and products are developed. As the population becomes more skilled and interested in development, new and improved import-replacing and export activities will develop.

The following are offered as examples. As the demand for higher skill levels and employment increase, there will be increased interest in education, which may also lead to increased pursuit in becoming teachers, resulting in import replacement of non-Indian teachers. As interest in employment increases, there may be a concomitant breakdown of the supposed cultural avoidance of manufacturing activity. Following modem management and production techniques, manufacturing employment need not be tedious, repetitive assembly line-type work; rather, it can be interactive and productive.

Much more importantly, the increased socioeconomic structure of the Rosebud Sioux society, stemming from the above-mentioned employment- and income-producing activities, will lead to increased interest in the culture and history of the tribes especially by members of the younger generation. When the dayto-day problems of subsistence are solved, there is more time for understanding and listening to the elders' concerns and history. Thus, the cultural integrity of the tribe is sustained and advanced.

As the economy of the reservation develops, the tribe increases its sovereign powers because of its reduced dependency on the federal govemment. Further, as development progresses, tribal members will gain expertise and experience, thus reducing the tribe's reliance on outside technical assistance.

\section{v. CONCLUSIONS}

Readers familiar with the problems of Indian country are now thinking of the obvious and other arguments with the development plan set forth above. However, all readers are to be encouraged and reminded of the cultural ideals of $\mathrm{Na}$ tive Americans: we remember our forebearers and those of them; we plan for our 
children and our children's children. In other words, the redevelopment of the Native American vitality is not a short-term proposal. And tribes accept that truth.

The above discussion notwithstanding, Indian country faces severe difficulties with any development paradigm. These difficulties include the available labor force, human capital development, transportation, capital funding and formation, the need for technical assistance and management, entrepreneurial risk-taking, the separation between business and politics via an economic development corporation, tribal government stability, and most importantly, cultural and sovereign integrity. ${ }^{16}$ Although these issues are beyond the scope of the current paper, progress is being made on all fronts. Keeping in mind the inherent difficulties facing any economy as impoverished as Rosebud, the Jacobs paradigm provides a framework to build upon as the process evolves.

A well-developed plan of action incorporating import replacement, product innovation, and export development is needed to "jump start" the economy of the Rosebud Sioux and many other tribes. Of course, this jump start may require 1020 years for fruitful outcomes, but there has to be a starting point. No one business venture is the key; rather, a variety of enterprises making use of available resources (and agglomerative factors shared by such enterprises) is required to get the economy moving in a positive direction. This final section intertwines the various ideas presented above.

Quick calculations based on available numbers show that Rosebud has an unemployed population of approximately 4,300 people. ${ }^{17}$ Clearly, no single enterprise is likely to make a significant dent in the current situation. A major manufacturing plant, employing as many as 500 people, would just begin to reduce the unemployment on the reservation. Of the projects suggested by Diamant, the largest would employ roughly 50 people. Combined, the enterprises may employ 2-300 in the initial stages. Therefore, looking for a panacean development activity is likely to leave tribal leaders disappointed.

However, understanding development as a process, rather than a black or white phenomenon, leaves the planner with an optimistic vantage point on the possibilities of success. It is this process orientation that holds the focal point of this paper. Jacobs's model provides a paradigm for the development process: one that puts us in a position to fully understand the development possibilities at Rosebud as well as the problematic areas.

White (1990) concludes his work by recognizing that the four reservations in his study have only begun to reach the point where they can address the serious socioeconomic problems resulting from years of inept federal policies. After 20 years, or more, of success relative to other reservations, the four subject reservations are only now in a position to address the difficulties of suicide, alcoholism, 
diabetes, low life expectancy, and the like. Without a lengthy time horizon, there is truly little hope for other less successful reservations.

Tribal sovereignty and self-determination are the mainstays of current development plans. These goals can only be truly realized if and when the population becomes self-supporting and the tribe ceases its dependency on the federal govemment. By developing a vigorous cycle of economic growth, the tribe will be able to fulfill these goals.

The tribe must take the position of searching for long-term growth. For Rosebud to move from its current state of 86 percent unemployment (and concomitant social problems) to the growth and prosperity of true self-determination and self-sufficiency, a time horizon of at least $15-20$ years is necessary. Native Americans are renowned for their concern for past, and future, generations. The sacrifice and efforts of the current generation will, if properly formulated, allow the future generations to regain their hold on sovereignty and culture. The Rosebud Sioux, and all First Nations, have the ability and determination to see this dream come true.

\section{ENDNOTES}

1. See Grand Canyon Trust (1992) and First Nations Financial Project (1991) for detailed discussions of these projects.

2. The Oglala Sioux Tribe at Pine Ridge, which neighbors Rosebud, may actually "win" this competition.

3. Due to problems with the Bureau of the Census, employment and income data are not locally available at this writing. STF 3 will include these data. These more detailed data will allow for more advanced statistical treatment than is presented herein. However, the point of this section is not to prove the obvious facts of poverty, etc., on the Rosebud Sioux reservation; rather, the point is simply to provide a brief oversight of the situations present.

4. All data comes from 1990 U.S. Census of Population and Housing, STF 1 A.

5. The statistics for Rosebud Sioux are not distinct or significantly different from many other reservations. In related work, the author has studied eight other reservations across the country. In one case, the distribution is only slightly shifted upward due to a large non-Indian retirement village on the reservation. The other reservations all show in excess of 40 percent of the population under 18.

6. Small, minority, and women-owned businesses can obtain 8(A) certification. This is a Department of Defense set aside program. Major contractors are re- 
quired, when possible, to devote a portion of their subcontracting work to 8(A) firms. These firms are able to negotiate subcontracts even if they are not the lowcost firm.

7. Albeit Jacobs focuses on the importance of a city-based economy, the current context focuses on adapting this paradigm to regional- and reservation-based economies. See below.

8. As anecdotal evidence, the following is offered. On a recent trip from southem Utah to Flagstaff, Arizona, on a Saturday evening, the traffic heading south from the Navajo Nation was particularly sparse; however, the traffic heading from Flagstaff onto the reservation was continuous and bumper to bumper at times. Clearly, reservation residents were returning home after a day in the border town.

9. Nor is the reality of comparative advantage and trade a two-product process. Given the multitude of goods and services in the modem economy, the direction of trade for any one good may reverse, or trade of one specific good may simply cease as conditions change. For example, recall how the directions and types of trade have changed between the United States and Japan in the last 30 years.

10. Of course, the impacts of the NAFTA agreement may reduce this comparative advantage.

11. The Mentor-Protege legislation (Section 1207 of P.L. 99-661) allows major defense contractors to form very close linkages with Small Disadvantaged Businesses beyond the scope of 8(A) certification. The major contractor provides technical assistance, equipment, training programs, and the like to the subcontractor. In retum, the major firm is able to apply these costs-multiplied by various factors depending on the type of assistance-toward their required 5 percent set aside. See Reed Smith et al. (1991) for more details.

12. During 1992, the author visited several reservations for the many faceted purposes of NEEPNAL. These purposes include educating tribal leaders, technical assistance consulting, and gaining primary information for research purposes. The relevant interviews are cited in the reference list.

13. Steve Cornell emphasized the importance of this point.

14. Development of a shopping center, including Walmart and a supermarket, is under way. Again, this facility will serve the city of Prescott as well as the reservation population. Besides earning rents and revenues from the gaming operation, the tribe charges a privilege charge equal to the state sales tax.

15. This point holds true for the remaining enterprises. The multiplier effect also holds for this aspect.

16. A full discussion of these issues is beyond the scope and space limitations of this paper. A detailed discussion is available as a supplement from the 
author. The interested reader is also directed toward White (1990) for a general discussion of successful development practices, Comell and Kalt (1992) for a discussion of institutional issues, and Smith (1993) for a discussion of cultural and sovereign integrity issues.

17. Five thousand people of working age with an 86 percent unemployment rate (Diamant 1988).

\section{REFERENCES}

Cornell, Stephen, and Joseph P. Kalt, eds. What Can Tribes Do? Los Angeles: University of Califomia, 1992.

Diamant, Adam. "Economic Development Opportunities: The Rosebud Sioux Indian Reservation, Rosebud, S.D." The Harvard Project on American Indian Economic Development, John F. Kennedy School of Government, Cambridge, May 1988.

Endfield, Marilyn, general manager of Apache Aerospace (White Mountain Apache Tribe). Interview with author. April and May 1992.

First Nations Financial Project. First Nations: Ten Year Report. Falmouth, Va.:

First Nations Development Institute, 1991.

Grand Canyon Trust. "Proceedings of The Colorado Plateau Community Initiatives Symposium Coping With Change: Economy and Environment." Flagstaff: Grand Canyon Trust, 1992.

Jacobs, Jane. Cities and the Wealth of Nations. New York: Random House, 1984. Pomice, Eva, and Dana Hawkins. "Delivering the Goods." US News and World Report (July 13, 1992): 51-52.

Reed Smith, Shaw \& McClay. "Pilot Mentor-Protege Program." Mimeo, McClean, Virginia, 1991.

Smith, Dean Howard. "The Circle of Federal Policy, Cultural Integrity, and Economic Development Concerning the Case of Native American Tribes: A View Backward and An Examination of the Future." Mimeo (in review), Flagstaff, Arizona, 1993.

Steele, John YellowBird, president, Oglala Sioux Tribe (Pine Ridge Reservation). Interview with author. August 1992.

Ward, Barbara. The Rich Nations and the Poor Nations. New York: Norton, 1962. White, Robert H. Tribal Assets: The Rebirth of Native America. New York: Henry Holt and Company, 1990.

Yazzie, R. "Convenience Stores: The Third Wave of Navajo Retail Outlets." Navajo Nation Economic Development Forum 1 (November-December 1989). 